DOI: $10.19195 / 2353-8546.4 .3$

\author{
KAROLINA PRYKOWSKA-MICHALAK \\ Uniwersytet Łódzki (Łódź, Polska)
}

\title{
Teatr niemiecki i teatr polski w początkowym okresie transformacji ustrojowej
}

German and Polish theatre in the initial period of the political transformation. During the first theatre seasons of the nineties, German drama focused on the analysis of the social traumas following the fall of the Berlin Wall, German reunification and perestroika. However, it soon became apparent that the theatre was not able to keep pace with the political changes of the times, and it failed to do justice to their internal complications and discrepancies.

The fascination with the new dramatic scenic forms originating in Germany, which could be observed in Poland in the second half of the nineties, had nothing to do with the so-called reunification drama. It more likely resulted from its fiasco and the adoption of new aesthetics and communication methods. The strengthening relation of the German and Polish theatre, i.e. joint festivals, inspired those Polish artists who sought for a new scenic language and transposed the German theatre experience into their own plays in a creative way. The scale of this movement was so extensive that it could be described as a kind of phenomenon in modern art and in relations between Poland and Germany.

Keywords: German drama, German and Polish theatre after the fall of the Berlin Wall, culture transfer

Das deutsche und das polnische Theater in der Anfangszeit der Systemtransformation. Die politischen Transformationen ' 89 hatten großen Einfluss auf die Veränderungen in Kunst und Kultur, und zwar nicht nur mit Bezug auf Deutschland und Polen, sondern vielmehr in weiten Teilen Ost- und Mittel-Osteuropas.

Die deutsche Dramaturgie konzentrierte sich in den ersten Theatersaisons der 90er Jahre vorwiegend auf die Verarbeitung der aus dem Mauerfall, der Wiedervereinigung Deutschlands sowie der Perestroika resultierenden gesellschaftlichen Veränderungen (in Kultur- und Künstlerkreisen wird auch ein

* Adres do korespondencji: Instytut Kultury Współczesnej. Wydział Filologiczny Uniwersytetu Łódzkiego, ul. Pomorska 171/173, p. 3.11, 90-236 Łódź. E-mail: kprykows@uni.lodz.pl. 
traumatischer Zustand betont). Es zeigte sich jedoch schnell, dass das Theater weder mit dem Tempo der politischen Ereignisse mithalten noch ihren inneren Verwicklungen und Widersprüchen gerecht werden konnte.

Die in Polen seit Ende der 90er Jahre beobachtete Faszination von neuen dramatisch-schauspielerischen Formen aus Deutschland hatte nichts mit der sogenannten Dramaturgie der Wiedervereinigung zu tun. Sie entstand vielmehr aus deren Misslingen und der Aufnahme einer neuen Ästhetik bzw. neuen Kommunikationsmethoden. Die immer enger werdenden Kontakte zwischen dem deutschen und dem polnischen Theater (z. B. über gemeinsame Festivals) wurden zur Inspiration für polnische Kunstschaffende, die eine neue szenische Sprache suchten und ihre Erfahrungen mit dem deutschen Theater kreativ in eigene Inszenierungen transponierten. Die Verbreitung dieser Erscheinung war so weitreichend, dass von einem Phänomen in der zeitgenössischen Kunst sowie den künstlerischen Beziehungen zwischen Polen und Deutschland gesprochen werden kann.

Schlüsselwörter: deutsch Dramaturgie, deutsche und polnische Theater nach dem Fall der Berliner Mauer, Kulturtransfer

Wydarzenia na scenie politycznej w 1989 i 1990 roku zarówno w Polsce, jak i w Niemczech były tak doniosłe, a jednocześnie przebiegały tak szybko, że reakcja ówczesnego teatru wydaje się mało adekwatna. Analizując dziś, dwadzieścia pięć lat po zburzeniu muru berlińskiego, repertuar teatru polskiego i niemieckiego pierwszych lat po transformacji ustrojowej, można postawić tezę, że właściwa reakcja na zjednoczenie Niemiec, a w Polsce na zmianę ustroju państwowego, znalazła swoje miejsce dopiero w teatrze i dramacie „doby przyspieszenia”, czyli okresie, za którego początek uznać możne manifest Thomasa Ostermeiera z 1999 roku, zatytułowany Teatr $w$ dobie przyspieszenia ${ }^{1}$.

W niemieckim teatrze pierwszego dziesięciolecia nowego państwa wyróżnić można trzy fazy powstawania nowych sztuk: pierwsza z nich to tzw. dramat zjednoczeniowy, tworzony przez dojrzałych autorów z zachodnich Niemiec, między innymi Botho Straussa czy Herberta Achternbuscha. Sztuki obu wymienionych dramatopisarzy dotykały problemu podziału Niemiec, frustracji obywateli wschodniej części i już w 1991 roku (wtedy ukazał się Schlusschor Straussa) nie dawały żadnej optymistycznej wizji przyszłości.

Dramat Schlusschor (Finałowy chór) Botho Straussa, którego akcja dzieje się w listopadzie 1989 roku, a ostatni akt pokazuje, jak runął berliński mur, wystawiony został najpierw w monachijskim teatrze Kammerspiele w reżyserii Dietera Dorna (maj 1991), a następnie zaprezentowany w czasie 28. Theatertreffen w Berlinie. Tytuł tego utworu, jak pisze Hans-Peter Bayerdörfer ${ }^{2}$, miał nawiązywać do Ody do radości z IX Symfonii Beethovena, którą grano przy różnych państwowych okazjach, w chwilach gdy nie wypadało zagrać hymnów narodowych któregoś z państw niemiec-

${ }^{1}$ Por. T. Ostermeier, Teatr $w$ dobie przyspieszenia, tłum. K. Wielga, „Didaskalia” 2000, nr 84.

${ }^{2}$ H.-P. Bayerdörfer, Niemiecki teatr w latach zjednoczenia 1989-1990, tłum. M. Sugiera, „Dialog” 1994, nr 3, s. 92. 
$\mathrm{kich}^{3}$. Strauss w swoim dramacie pokazał kilka epizodów, zwieńczonych w finale fetą i euforią, towarzyszącymi burzeniu muru. W pierwszym akcie zatytułowanym Widzieć i być widzianym chór zajmuje miejsce na marmurowych schodach i pozwala się fotografować w oczekiwaniu na występ, który jednak nie rozpoczyna się, w końcu jedna z chórzystek obnaża się, a kiedy inna postać intonuje Deutschland, Deutschland!, wszyscy stają na baczność. W drugim obrazie kontynuowany jest motyw nagiej kobiety - Delia, jak pisała prasa niemiecka, to prototyp ekscentrycznej damy $\mathrm{z}$ wyższych sfer, która w czasie przyjęcia ustawia w przedsionku domu lustro. Mają się w nim przejrzeć wszyscy goście, jeden z nich rozpoczyna śpiewać Deutschland, Deutschland! Podziały, jakie rysują się w społeczeństwie niemieckim, widać najdobitniej w trzecim akcie. Ironiczna wizja braterstwa i pojednania Niemiec Zachodnich i NRD, jaką przyjęli autor tekstu i monachijski reżyser, potraktowana została bardzo poważnie, choć już w 1991 roku pisano, że „dramat Botho Straussa ma dopiero trzy

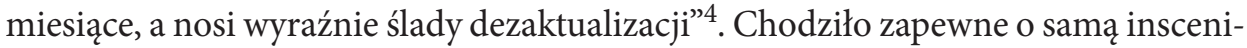
zację Dorna, przygotowaną na pudełkowej scenie, prawie monochromatyczną, epatującą chłodem. Sztukę Straussa wystawił wkrótce (1992) w berlińskiej Schaubühne Luc Bondy, a w dwudziestą piątą rocznicę zburzenia muru berlińskiego w granicznym mieście Hof - Caroline Stoltz. Reżyserka zamknęła fragmentaryczną strukturę dramatu w kilku slapstickowych scenach ${ }^{5}$, obnażających patos sztuki Straussa, z której publiczność w Theater Hof mogła się śmiać. Okazuje się bowiem, że publiczność Niemiec Zachodnich w 1990 roku nie reagowała pozytywnie na gatunki tradycyjnie budzące śmiech. Taką sztuką była na przykład farsa wykorzystywana przez dramat zjednoczeniowy Aufverlorenen Posten (Na straconej pozycji) Achternbuscha, wystawiony w teatrze Kammerspiele w Monachium w kwietniu 1990. Była to historia mieszkańca wschodnich Niemiec, wyjeżdżającego na Zachód, którą później socjologowie opisywali jako typowy scenariusz zachowań społecznych okresu transformacji. Chodziło bowiem o fascynację zwykłą codzienną konsumpcją, utożsamieniem szczęścia $\mathrm{z}$ dobrobytem materialnym, zakupami w supermarkecie, tanimi wczasami na egzotycznych wyspach. W zakończeniu tej sztuki, pisze Bayerdörfer, jest znamienna scena, w której widzimy szesnastu mieszkańców wschodnich landów wysiadających z wartburga: „jedząc banany rozchodz[ą] się po scenie"6. Na deskach monachijskiego teatru, odwiedzanego głównie przez intelektualnej elity, fragment ten nie wydawał się wcale śmieszny.

Druga faza dramaturgii początkowego etapu transformacji sięgała po nowe typowo polityczne tematy, wtedy też nastąpił okres dyskusji nad kształtem nowego niemieckiego teatru oraz praca nad nowym repertuarem, która rozpoczęła się od edukacji kulturalnej podjętej przez takie teatry, jak: Schillertheater z Berlina w se-

\section{${ }^{3}$ Ibidem.}

${ }^{4}$ Ibidem.

${ }^{5}$ Por. http://www.die-deutsche-buehne.de/Kritiken/Schauspiel/Botho+Strauss/Schlusschor/ Bildstarker+Slapstick [dostęp: 1.01.2015].

${ }^{6}$ Por. H.-P. Bayerdörfer, op. cit., s. 92. 
zonie 1990-1991 oraz Kammerspiele Monachium. W ich program wpisywały się wykłady i publiczne czytania dramatów oraz innych utworów literackich w celu projektowania i poszukiwania nowej niemieckiej tożsamości. W kolejnych trzech sezonach powstało kilka sztuk komentujących bieżące sprawy, wydarzenia polityczne (Kommunisten Jörga-Michaela Koerbla, Bill kehrt zurück Klausa Pohla), rozpad imperium radzieckiego (Gorbatschow - Fragment Michaela Koerbla), problemy np. skinheadów ${ }^{7}$. Bayerdörfer na koniec swojego artykułu o niemieckim teatrze w latach 1989-1991, w którym głównie analizuje dramaturgię, stawia bardzo trafną diagnozę jej stanu i proponuje nowe rozwiązania, za którymi teatr niemiecki zacznie podążać dopiero w drugiej połowie lat dziewięćdziesiątych:

Niemiecka dramaturgia ostatnich trzech lat $\mathrm{z}$ ogromną trudnością dotrzymuje kroku wydarzeniom politycznym, nie potrafiąc oddać sprawiedliwości ich wewnętrznym komplikacjom i sprzecznościom. Rzeczywiście, w obliczu problemów, jakich nastręcza zjednoczenie polityczne na płaszczyźnie gospodarczej, społecznej i przemian świadomości, zjednoczenie teatru okazało się względnie łatwe. Nikt jednak nie zaprzeczy, że jednym z zadań sceny jest ingerencja w społeczną mentalność, by burzyć stare i tworzyć nowe wyobrażenia. Nie da się tego robić przez proponowanie udogodnień i uniwersalnych rozwiązań, klucz — jeśli w ogóle istnieje — leży w podejmowaniu małych tematów codziennego życia, w zaczynaniu od portretowania detali ${ }^{8}$.

Fakt ten potwierdza także teza stawiana już ex post, bo w 2004 roku przez Johna von Düffela ${ }^{9}$, który uważa, że eksplozja nowej niemieckiej dramaturgii końca lat dziewięćdziesiątych nie była taka oczywista. Düffel zwraca uwagę, że znaczący wpływ na rozwój dramatu niemieckiego w tym okresie miała dramaturgia austriacka, przede wszystkim Wernera Schwaba oraz Elfriede Jelinek. Dramaturgia niemiecka po okresie rozliczeń wewnątrznarodowych i pozjednoczeniowych, czyli w trzeciej fazie, zwróciła się w stronę realizmu. Było to związane z potrzebą oglądania w teatrze otaczającej rzeczywistości, zwrócenia uwagi na odbiorcę oraz wzięcia pod uwagę radykalnych przemian społeczno-politycznych, jakie dokonały się po zjednoczeniu Niemiec. Teatr i dramat charakteryzowano jako „nowy realizm”, gdyż — jak zapowiadał w 1994 roku Bayerdörfer - podejmował tematykę społeczno-obyczajową, zwracając się w stronę „małych tematów codziennego życia, w zaczynaniu od portretowanie detali” 10 , prezentował je w specjalnie wyostrzonym obrazie, „operował strategią szoku w celu emocjonalnej identyfikacji, [...] tak by widz miał nieodparte wrażenie, że dzięki nim teatr podejmuje na nowo próbę krytycznego odzwierciedlenia otaczającej rzeczywistości”" ${ }^{11}$.

${ }^{7}$ Por. Skinheadzi w teatrze, Kronika, „Dialog” 1992, nr 12.

${ }^{8}$ H.-P. Bayerdörfer, op. cit., s. 94.

${ }^{9}$ Por. J. von Düffel, F. Schößler, Gespräch über das Theater der neunziger Jahre, Sonderband Theater fürs 21. Jahrhundert, „Text+Kritik” 2004, s. 42-51.

${ }^{10}$ H.-P. Bayerdörfer, op. cit., s. 94.

${ }^{11}$ M. Borowski, M. Sugiera, Gry w fikcję i o fikcję. Teatr i widzowie w nowym dramacie, [w:] Postmosty. Polacy i Niemcy w nowej Europie, red. G. Matuszek, Kraków 2006, s. 199. 
Prekursorem tego nurtu „nowego realizmu” był wspominamy już na wstępie Thomas Ostermeier, reżyser i dyrektor berlińskiej Schaubühne, który uważał, że dzięki nowym dramatom młodych autorów odbudowana zostanie więź między teatrem a rzeczywistością. Swoje postulaty naprawy niemieckiego teatru wygłosił w przytoczonym już wyżej przemówieniu Teatr $w$ dobie przyspieszenia w maju 1999, podczas konferencji „Wiek XX. Sztuka w Niemczech” w berlińskim Muzeum Sztuki Współczesnej Hamburger Bahnhof. Omawiając kryzys teatru, twórczości dramatopisarskiej oraz marazm, jaki w jego opinii dotknął niemiecki teatr w latach dziewięćdziesiątych po śmierci Heinera Müllera, Ostermeier przytacza wiele prozaicznych powodów, związanych ściśle $\mathrm{z}$ rozczarowaniem bieżącą sytuacją, tworzeniem nowego systemu hierarchii wartości, ale unikając jasnej artykulacji wniosków, omija problem postzjednoczeniowych relacji wewnątrz Niemiec.

Efekty działalności Ostermeiera, między innymi jego współpracy z młodymi dramatopisarzami, niemiecka publiczność mogła oglądać już od 1996 roku na scenie Die Baracke, a później w berlińskiej Schaubühne. Znaczenia postulowanemu „nowemu dramatowi” przydały także spektakularne sukcesy i nagrody dla zespołu Ostermeiera $^{12}$, które zwróciły uwagę krytyki oraz środowiska artystycznego na „nowy dramat” i potrzebę zmiany pokolenia reprezentującego główny nurt teatru. Wywołało to także, jak dotąd niespotykany, przyrost liczby debiutów dramatopisarskich oraz falę nowych tekstów dla teatru. Co prawda już od połowy lat dziewięćdziesiątych drukowano w Niemczech dramaty, które podobnie jak brytyjski nurt in yer face ${ }^{13}$, reprezentowany między innymi przez Sarah Kane oraz Marka Ravenhilla, tematyzowały przemoc, społeczne patologie, dysfunkcje rodzinne i problem wykluczenia społecznego, ale skala tego zjawiska nie była wtedy jeszcze tak znacząca. Wielość i różnorodność zrodziła problem braku możliwości jakiegokolwiek usystematyzowania tego nurtu.

Małgorzata Sugiera oraz Mateusz Borowski we wstępie do antologii najnowszych sztuk niemieckich pod znaczącym tytułem Wielość teatrów piszą:

Ostermeier nie pomylił się [...], że nowe teksty powstaną jako rezultat wielorakich prób odtwarzania [...] - pępowiny łączącej teatr z rzeczywistością. Zapewne jednak nie przewidział tej rozmaitości artystycznych i scenicznych konwencji, perspektyw i sposobów prezentacji obrazów świata czy odmienności proponowanych form nawiązania kontaktu między sceną a widownią, jaka cechuje teksty pisane dla niemieckich scen w ciągu ostatniej dekady ${ }^{14}$.

12 Premierowe sztuki na scenie Die Baracke am Deutschen Theater Berlin w latach 1996-1999: Nicky Silver, Fette Männer im Rock (1996); David Harrower Messer in Hennen (1997); Mark Ravenhill, Shoppen \& Ficken (1998).

13 Por. M. Sugiera, Realne światy/możliwe światy, Kraków 2005, s. 21; por. A. Sierz, In-Yer-Face Theatre, London 2001.

${ }^{14}$ M. Borowski, M. Sugiera, Wariacje na formy i wspomnienia, [w:] Wielość teatrów. I Antologia najnowszych sztuk niemieckich, red. M. Borowski, M. Sugiera, A. Wierzchowska-Woźniak, Kraków 2005, s. 9. 
Jedynym wspólnym mianownikiem stał się więc przymiotnik „nowy”, a w polskim życiu teatralnym częściej używano zamiast niego określenia „brutaliści”. Wkrótce nazwa ta - obok „nowy dramat” - zaczęła funkcjonować jako kategoria wyróżniająca twórczość niemieckich autorów końca lat dziewięćdziesiątych i początku wieku dwudziestego pierwszego. „Nowy” oznaczał zarówno samych autorów — zazwyczaj debiutujących na profesjonalnych scenach, odnosił się także do zawartych w manifeście Ostermeiera postulatów tworzenia „nowego dramatu”, „nowego realizmu" - odpowiadającego współczesnemu odbiorcy, którego — zdaniem reżysera - charakteryzuje fragmentaryczne postrzeganie świata „wyszkolone na filmie i telewizji" ${ }^{15}$, domaga się więc on nowej formy dramatycznej oraz nowych treści.

W latach dziewięćdziesiątych do teatru chodziły pierwsze pokolenia wychowane $\mathrm{w}$ dobie powszechnego dostępu do wielu kanałów telewizji oraz techniki wideo, zafascynowane atrakcyjną oprawą medialną, prezentowaną między innymi przez stacje muzyczne szczególnie popularne w latach osiemdziesiątych i dziewięćdziesiątych. Socjologowie nazywają to pokolenie generacją MTV, wskazując na znaczący wpływ tej stacji na kształtowanie postaw społecznych, trendów, mód i zachowań. Ostermeier, odwołując się właśnie do tych młodych ludzi, wyjaśnia, że „nowy dramat” nie może zrezygnować ze scen przemocy, agresji czy aktów seksualnych, często wulgarnych, ponieważ to właśnie one wiążą teatr z rzeczywistością.

Można więc stwierdzić, że niemiecka dramaturgia końca lat dziewięćdziesiątych jest efektem licznych działań okołoteatralnych oraz pozaartystycznych, a także instrumentów wspierających, poczynając od apelu Ostermeiera przez promocję młodych dramatopisarzy w czasopismach teatralnych, agencjach wydawniczych, a na fali festiwali dramaturgicznych kończąc.

Pierwsze sezony w polskim teatrze po 1989 roku charakteryzowano często jako „okres pustki” zawiedzionych nadziei pokładanych w takich autorach, jak Różewicz czy Mrożek. Zarówno w prasie fachowej, jak i pracach naukowych lata tuż po transformacji ustrojowej opisuje się jako kryzys rodzimej twórczości ${ }^{16}$. Jacek Sieradzki diagnozuje tę sytuację twórczego wypalenia jako wynik represji wprowadzonych po stanie wojennym.

Represje nie miały charakteru fizycznej pacyfikacji, ale o pacyfikacji psychicznej można mówić: odbierały nadzieję. [...] Stan wojenny podciął też skrzydła całemu pokoleniu wchodzącemu w dorosłe, twórcze życie; wypalili się szybciej, niż przewidują normy, pozostały po nich vacaty we wszystkich dziedzinach twórczości, w teatrze i dramaturgii też. Czy można się więc dziwić, że po 1989, kiedy komunistyczną cenzurę odesłano do lamusa, wszelkie nadzieje na genialne utwory pisane ponoć 'do szuflady' okazały się płonne? Szuflady były puste. Rzekłoby się, krzycząco puste ${ }^{17}$.

15 T. Ostermeier, op. cit., s. 17.

${ }^{16}$ Por. T. Kubikowski, Pustka i forma, [w:] Strategie publiczne, strategie prywatne, teatr polski 1990-2005, red. T. Plata, Warszawa 2006; Ł. Drewniak, Grzegorz Jarzyna. Ojciec Dyrektor, „Przekrój” 2006, nr 38; J. Sieradzki, Trudna wolność. Dramaturgia po 1989 roku, „Ade Teatro” 2002, nr 9, http:// www.culture.pl/pl/culture/artykuly/es_dramaturgia_wolnosci [dostęp: 1.01.2015].

17 J. Sieradzki, op. cit., 
W swoim „sprawozdaniu z życia dramaturgii w wolnej Polsce” (tak Sieradzki określa swój tekst Trudna wolność. Dramaturgia po 1989 roku) ${ }^{18}$ autor analizuje dramaty, które powstały w latach 1987-2000, próbując odpowiedzieć na pytanie, dlaczego nie ma sztuk o wydarzeniach '89 i '90 roku; stwierdza, podobnie jak Tomasz Kubikowski, autor tekstu Pustka i forma otwierającego zbiór zatytułowany Strategie publiczne, strategie prywatne, teatr polski 1990-2005 ${ }^{19}$, że euforia wolności po transformacji ustrojowej 1989 roku i rozpadzie bloku wschodniego nie mogła zostać wyrażona w poważnej formie dramatycznej. Poetyka narodowo-wyzwoleńcza i martyrologiczna nagle przestały mieć znaczenie, a społeczeństwo zwróciło się w stronę kultury popularnej - wcześniej elitarnej, po '89 zaś dostępnej w skali masowej. Teatr także otworzył się na tę konsumpcję: przypomnijmy słynny spektakl $\mathrm{z}$ warszawskiego Teatru Studio zatytułowany Tamara, będący symultanicznie rozgrywaną sztuką, której akcja toczy się w willi włoskiego pisarza i faszysty Gabriele D’Annunzio. Gospodarzy odwiedza francuska malarka polskiego pochodzenia, Tamara Łempicka, a jej zamiarem jest portretowanie pisarza. Sztuka o kilkuwątkowej, lecz nieskomplikowanej fabule była pretekstem do zabawy. Roman Pawłowski pisze:

publiczność chodziła za aktorami po socrealistycznych wnętrzach Pałacu Kultury, a na koniec wszyscy spotykali się na wystawnym bankiecie. To połączenie konsumpcji artystycznej z gastronomiczną wyznaczało nową rolę dla teatru, który miał się stać snobistyczną rozrywką dla nowej klasy średniej ${ }^{20}$.

Prowadzono nawet pewne obserwacje dotyczące publiczności, jej statusu społecznego, albowiem cena biletu na ten spektakl, jak policzył Andrzej Wanat, „równa [była] dziesiątej części średniej pensji ${ }^{21}$. Trudno było jednak opisać typowego widza tego widowiska ${ }^{22}$. Tamara to absolutnie nowe wydarzenie $\mathrm{w}$ polskim teatrze i nie chodzi tu o symultaniczną akcję sztuki, lecz o nowe prorynkowe nastawienie Teatru Studio. Promocję tego spektaklu prowadzono w pełni profesjonalnie w wielu mediach warszawskich; plakaty i afisze znacznie odbiegały od dotychczas stosowanych. Był to więc spektakl, choć Wanat pisze, że to tylko „zdarzenie”, inicjujące zmiany w polskim teatrze. Kolejną produkcją przygotowaną z jeszcze większym rozmachem był musical Metro (premiera w styczniu 1991 roku).

Obraz polskiego odbiorcy dóbr kultury, zafascynowanego w pierwszych latach po transformacji kulturą napływającą z Zachodu, a w efekcie przez nią wchłoniętego, jest efektem rozwoju mediów, a nie radykalnej zmiany gustów estetycznych

18 Ibidem.

19 Por. T. Kubikowski, op. cit.

20 R. Pawłowski, 25 lat teatru $w$ wolnej Polsce. Czy jest wspólnota?, http://wyborcza. pl/1,75475,15814341,25_lat_teatru_w_wolnej_Polsce_Czy_jest_wspolnota_html [dostęp: 1.01.2015].

21 A. Wanat, Zdarzenie, „Teatr” 12 , 1990, http://www.e-teatr.pl/pl/artykuly/183770.html [dostęp: 1.01.2015].

22 Por. M. Piekut, W. Majcherek, Publiczność „Tamary”, „Dialog” 1990, nr 5/6, http://www.e-teatr. $\mathrm{pl} / \mathrm{pl} /$ artykuly/183640.html [dostęp: 2.01.2015]. 
- czytamy w Raporcie o stanie i zróżnicowaniach kultury miejskiej ${ }^{23}$. Zwrócenie się w stronę Zachodu było więc w wielu dziedzinach życia społecznego naturalnym odruchem pierwszych lat transformacji. Maria Janion stwierdziła, że „stan wojenny pogłębił romantyczną emocjonalność: manifestacje tożsamości narodowej wykorzystywały symbole, gesty i rytuały kultury romantycznej, zwłaszcza zaś martyrologicznego mesjanizmu"24. W sytuacji, kiedy zabrakło powodów do patriotycznych i wolnościowych manifestacji w sztuce, symboliczno-romantyczny paradygmat zaczął wygasać $^{25}$. Generacja, która była świadkiem tego procesu, nie zdawała sobie sprawy, że akceptując zmiany, jakie dokonały się w polityce, musi także pozwolić na zmiany w sferze sztuki. Odnosząc się nie tylko do literatury, lecz także do innych dziedzin życia, Janion stwierdza, że „bezkrytyczne »zakochanie we własnej piękności«, wpojone nam przez romantyków [...] ratujące nas w permanentnych stanach słabości, klęsk i upadku [po 1989] nie miało już szans dłuższego przetrwania"26.

Jeśli porównać doświadczenia teatru niemieckiego i polskiego tego samego okresu, to bilans wychodzi zdecydowanie na korzyść teatru polskiego, bo choć temat zmian ustrojowo-polityczno-społecznych nie znajdował miejsca w dramacie, to właśnie na początku lat dziewięćdziesiątych powstały ważne dla polskiego teatru dramaty, między innymi Antygona w Nowym Jorku Janusza Głowackiego („Dialog” 10, 1992).

Prapremiera sztuki Głowackiego odbyła się 13 lutego 1993 roku w warszawskim Teatrze Anteneum, widzowie nie oczekiwali jakiegoś nagłego objawienia ani eksperymentu. Recenzję, a raczej laurkę wystawił sztuce Jan Kott w opublikowanym w miesięczniku „Dialog” w październiku 1992 roku tekście Antygona powiesiła się $w$ Tompkins Square Park. Kott zaliczył sztukę Głowackiego do najważniejszy polskich dramatów w ostatnich latach. Porównując Antygonę w Nowym Jorku do Czekając na Godota Becketta, stwierdził, że choć „przyrównanie jest na wyrost, ale tak właśnie trzeba"27, autor Szekspira współczesnego zauważył bowiem, że dramat absurdu zapowiada nowy realizm ${ }^{28}$ i choć w 1992 roku jeszcze nie było w Polsce żadnych przesłanek transferu niemieckiego dramatu nowego realizmu, to Kott stwierdza, że tragifarsa Głowackiego, podobnie jak tragikomedia Becketta, jest bardziej okrutna niż tragedia i pokazuje bohaterów takich, jak my wszyscy. Jedna z postaci sztuki

${ }^{23}$ Raport o stanie i zróżnicowaniu kultury miejskiej, s. 21, http://www.kongreskultury.pl/ title,Raport_o_stanie_i_zroznicowaniach_kultury_miejskiej_w_Polsce,pid,357.html [dostęp: 1.01.2015].

${ }^{24}$ M. Janion, „Czy będziesz wiedziat, co przeżyteś”, Warszawa 1996, s. 9.

${ }^{25}$ Polemikę z prezentowanym tu stanowiskiem M. Janion prowadziła między innymi T. Walas („Zmierzch paradygmatu” i co dalej?, [w:] eadem, Zrozumieć swój czas. Kultura polska po komunizmie - rekonesans, Kraków 2003).

${ }^{26}$ M. Janion, op. cit., s. 15.

27 J. Kott, Antygona powiesiła się w Tompkins Square Park, „Dialog” 1992, nr 10, http://www.eteatr.pl/pl/artykuly/91317.html [dostęp: 1.01.2015].

28 „Nie przestaje mnie zdumiewać, że do nowego realizmu (światły Ket Puzyna powiedziałby może: do dojrzałego naturalizmu) prowadzi dramatyczna droga od tego, co może i zbyt pochopnie nazywaliśmy teatrem absurdu". J. Kott, op. cit. 
Głowackiego - Pchełka, emigrant z Polski - to postać z dramatu „okresu przejściowego", tzw. zmiany paradygmatu — snuje mityczne opowieści o swojej przeszłości i wizji przyszłości, ogarnia go niemoc niczym romantycznego bohatera - jej przyczyną jest wewnętrzna inercja, alkoholizm, bezdomność, brak pracy - dosięgają go więc problemy typowe dla postaci dramatu „nowego realizmu”. Roman Pawłowski opisując, w podsumowaniu ostatniego dwudziestolecia bohatera made in Poland ${ }^{29}$, przywołuje Pchełkę obok Bogusia z Made in Poland Przemysława Wojcieszka, Małej Metalowej Dziewczynki ze sztuki Doroty Masłowskiej Między nami dobrze jest. Pchełkę odnajdujemy także w sztukach Krzysztofa Bizio np. Śmieci, Toksyny, trudno więc nie uznać Antygony Głowackiego za pewien etap rozwoju współczesnego dramatu. Zapewne nie na taki dramat, czyli historię nowojorskich homlesów, czekano w pierwszych latach po transformacji ustrojowej w Polsce, wydawało się, że nie dotyczy to nas. Wkrótce jednak słynny epilog tej sztuki informujący o zwiększającej się liczbie bezdomnych i związanych z tym konsekwencjach stał się motywem nowych polskich sztuk dotykających wielu patologii społecznych.

W polskim teatrze $\mathrm{z}$ realizmem był zawsze problem. Małgorzata Sugiera zwraca uwagę, że po '89 nastał konflikt między oczekiwaniami, jakie stawiała przed teatrem publiczność wychowana przed odbiornikiem telewizyjnym, a tradycją polskiego dramatopisarstwa. Oczekiwano od teatru „portretowania codziennego świata widzów i ich problemów, zaś pozbawiony właściwie w ogóle tradycji realistycznego pisania dla sceny dramat [polski] nie bardzo potrafił sobie poradzić z tym wyzwaniem"30. Dlatego początkowo posiłkowano się obcą dramaturgią, która wkrótce na stałe zagościła na polskich scenach. Bliższy kontakt polskiego odbiorcy z nową dramaturgią Europy Zachodniej stał się możliwy po 1990 roku między innymi dzięki odnawiającym swoją międzynarodową formułę festiwalom teatralnym. Wcześniej, z powodu ograniczeń politycznych wewnątrz bloku wschodniego oraz procedur na przykład ruchu wizowego, festiwale teatralne miały ograniczone możliwości funkcjonowania w pełni na skalę międzynarodową.

Jeden z najpopularniejszych w Polsce dramatów nowego realizmu - Ogień w głowie Mariusa von Mayenburga — został zaprezentowany w 1999 roku na Międzynarodowym Festiwalu Teatralnym Kontakt w Toruniu. Thomas Ostermeier pokazał tę, dziś już można by powiedzieć kultową sztukę, budząc duże zainteresowanie, a nawet ogólne poruszenie środowiska teatralnego. Recepcja niemieckiego dramatu w Polsce była więc na początku związana $\mathrm{z}$ teatrem Ostermeiera. Z perspektywy dwudziestolecia dostrzegamy, że „nowy realizm i nowy dramat”, a także sztuki autorów brytyjskich, wystawiane w Niemczech między innymi właśnie w teatrze Ostermeiera w końcu lat dziewięćdziesiątych i na początku dwudziestego pierwszego

${ }^{29}$ R. Pawłowski, Bohater $z$ „Made in Poland”, „Gazeta Wyborcza”, dodatek „Duży Format” online, http://www.e-teatr.pl/pl/artykuły/85202.html [dostęp: 1.01.2015].

${ }^{30}$ M. Sugiera, op. cit., s. 20. 
wieku, stały się elementem swoistego transferu kultury, jaki zaistniał między teatrem polskim i teatrem niemieckim po $1990 \mathrm{roku}^{31}$.

W roku 1999 w lipcowym numerze miesięcznika „Dialog” opublikowano przekład sztuki Mariusa von Mayenburga Ogień w głowie (Feuergesicht) ${ }^{32}$ oraz notatkę o recepcji tego dramatu w Niemczech. Jego polska prapremiera odbyła się na zakończenie przeglądu zatytułowanego „Nowa Dramaturgia Niemiecka”, zorganizowanego w listopadzie 1999 w warszawskim Teatrze Rozmaitości. Przegląd miał na celu zapoznanie polskiej publiczności z twórczością dramaturgiczną naszych sąsiadów. Poza próbami czytanymi trzech dramatów: Alberta Ostermaiera The Making of B-Movie, Mariusa von Mayenburga Ogień w głowie oraz Theresii Walser Córki King Konga, w programie znalazły się również spotkania z autorami oraz Jensem Hillje - dramaturgiem, współpracownikiem Thomasa Ostermeiera, współtwórcą sukcesu sceny Die Baracke przy Deutsches Theater w Berlinie. Jak pisze Justyna Golińska:

chodziło raczej o uświadomienie, że pojawiła się ciekawa literatura, na którą warto zwrócić uwagę. Zaś spotkanie z Jensem Hillje, który modę na wystawianie tych dramatów podsyca, było próbą wyjaśnienia, dlaczego taki boom był możliwy i jakie płyną z tego korzyści dla współczesnej sceny ${ }^{33}$.

Wspomniany boom nowej dramaturgii w Polsce, w sezonie 1998/1999 dopiero się zaczynał i początki te okazały się bardzo trudne, a nawet na tyle nieudane, że istniała obawa, czy ten trend zyska zainteresowanie. Jako pierwsi dramaty brutalistów wystawiali Paweł Łysak i Paweł Wodziński, założyciele towarzystwa teatralnego, którego celem było wprowadzenie nowego, młodego dramatu na polskie sceny. Zmiana, która miała dokonać się za sprawą tej dramaturgii, związała się ze zwróceniem uwagi na odbiorcę, jego potrzeby i oczekiwania, zwrotem ku młodej generacji inaczej postrzegającej świat, wychowanej przez kulturę masową. Generację tę mieli do teatru przyciągnąć ich rówieśnicy, między innymi dramatopisarze posiadający podobną wrażliwość i perspektywę widzenia.

Polscy prekursorzy nurtu brutalistycznego żywili nadzieję, że sztuki zachodnich młodych autorów brytyjskich oraz niemieckich nie tylko staną się impulsem do pobudzenia zainteresowania teatrem młodej publiczności, ale też przyczynią się do powstania rodzimej młodej dramaturgii. Efekty ich pracy można było oglądać już w kolejnych sezonach. Polski boom dramatopisarski rozpoczął się około roku 2000, a pierwsza antologia zbierająca sztuki młodych polskich twórców pod redakcją Romana Pawłowskiego wydana została w Krakowie w 2003. Autor tej antologii pisze we wstępie, że dokonał wyboru dziesięciu utworów, choć mógłby wybrać ich dwa razy więcej ${ }^{34}$.

31 Więcej na ten temat pisałam w książce K. Prykowska-Michalak, Kurtyna w górę! Relacje między teatrem polskim i teatrem niemieckim po 1990, Łódź 2012.

32 M. von Mayernburg, Ogień w głowie, tłum. J. Diduszko-Kuśmierska, „Dialog” 1999, nr 7.

33 J. Golińska, Rozmaitości zza granicy, „Didaskalia” 1999, nr 34, s. 38.

34 Pokolenie porno i inne niesmaczne utwory teatralne, red. R. Pawłowski, Kraków 2003, s. 5. 
Główną cechą polskiej młodej dramaturgii, podobnie jak niemieckiej, stał się brak wspólnego mianownika. Potwierdziła to pierwsza antologia, zbierająca utwory o różnych tematach, odmiennych stylach pisarskich, języku oraz formie. Jedynym określeniem łączącym grupę młodych dramatopisarzy stał się paradoksalnie tytuł jednej ze sztuk, zamieszczonej w omawianym tomie - Pokolenie porno!. Slogan ten lokuje prezentowanych autorów w generacji debiutów początku dwudziestego pierwszego wieku, młodych ludzi, którzy rozpoczynali dorosłe życie już w wolnej, kapitalistycznej Polsce lat dziewięćdziesiątych. Jakkolwiek Pawłowski zastrzega we wstępie, że antologia jest najczystszą, niczym nieinspirowaną „sztuką dla sztuki”, to trudno nie odnieść wielu wątków, postaci czy stylu wypowiedzi do niemieckiej dramaturgii. Nie chodzi tu wcale o bezpośrednie powiązania, inspiracje czy remake, lecz o sam trend pisania przez młodych ludzi sztuk o sprawach ich dotyczących i ich własnym językiem. Niemieccy autorzy „nowej dramaturgii” pokazali polskim kolegom znaczenie teatru realistycznego, opartego na problemach i zmaganiach przede wszystkim z rzeczywistością kapitalizmu i wolnego rynku.

Shakespeare uważał, że teatr to streszczona żywa kronika czasu ${ }^{35}$. Teatry polski i niemiecki w pierwszych sezonach po upadku komunizmu zajęły się tym, co $\mathrm{z}$ ich perspektyw było najważniejsze, wtedy jeszcze perspektywy te były rozbieżne, ale wkrótce dzięki wielu czynnikom warunkującym transfer kultury relacje między teatrem polskim i teatrem niemiecki zmieniły się znacząco.

35 W. Shakespeare (Hamlet, akt II, scena 2): „teatr to streszczona, żywa kronika czasu ”. 